\title{
Evaluation of mineral content and heavy metals of dromedary camel milk in Iran
}

\author{
Mahdieh MOSTAFIDI ${ }^{1}$, Maryam MOSLEHISHAD ${ }^{2 *}$, Zahra PIRAVIVANAK ${ }^{3}$, Zohreh POURETEDAL ${ }^{3}$
}

\begin{abstract}
The aim of this study was to determine the amount of major mineral compounds and heavy metals of camel milk in Iran. For this purpose camel milk samples were collected from seven regions of Iran include Qazvin, Golestan, Semnan, Sistan-Baluchestan, Khuzestan, Bushehr and Tehran. The samples were analyzed using Inductively Coupled Plasma-Optical Emission Spectrometer (ICP-OES) method. The results showed that among the mineral contents, iron and zinc of camel milk were greater than bovine milk. Based on the codexstandard 193-2007 standards, the maximum acceptable limit for lead and cadmium is $20 \mu \mathrm{g} / \mathrm{kg}$ and $10 \mu \mathrm{g} / \mathrm{kg}$, respectively. The results of this study showed that the measured amounts of lead, cadmium and nickel in all samples were less than the acceptable limit for bovine milk. Bovine milk and dairy products are a poor source of iron, while the obtained data revealed that camel milk is a major source of minerals, especially iron. The camel milk's iron was 10 times more than bovine milk. However, variations in mineral content in camel milk could be due to feed, stage of lactation, milk collection time, drought conditions, environmental conditions and associated analytical methods. Camel milk recommended as a valuable source of food for the human.
\end{abstract}

Keywords: camel milk; mineral element; heavy metal; Inductively Coupled Plasma (ICP).

Practical Application: This study allows knowing the amount of some mineral content and heavy metals of camel milk in Iran.

\section{Introduction}

Camel milk is considered as the most important source of milk provision in desert. It contains health-promoting nutrients for human beings (Farah et al., 1992). Camel milk do not have allergenicity properties because it does not contains $\beta$-lactoglobulin (Mankinen \& Palosuo, 1992; Ahmed et al., 2014). Recent studies revealed that camel milk has anti-diabetic property due to the presence of special protein like insulin, (Zagorski et al., 1998; Agrawal et al., 2007) as well as antioxidant and antimicrobial capacities (Salami et al., 2010).

Physical and chemical properties of camel milk are highly dependent on nutritional status, environmental and genetic parameters (El-Agamy et al., 2009). The amount of camel milk protein is between $2 \%$ to $5.5 \%$ and roughly similarto bovine milk (Shabo et al., 2005; El-Agamy et al., 2009). Camel milk's fat ranges from 2.6 to $5.5 \%$ depending on the quality of the fodder and the quantity of the drinking water, the number of lactation periods and food conditions and so similar to bovine milk in average (Yasin \& Wahid, 1957). Lesser percentage of short-chain fatty acids ( $\mathrm{C} 4$ to $\mathrm{C} 12)$ is one of the properties of the camel milk's fat which cause the softer and higher crystallization point than bovine milk (Farah et al., 1989; Farah \& Rüegg, 1991). The average amount of lactose as the most important carbohydrate in camel milk $(4.62 \%)$ is a little less than the lactose amount of bovine milk (4.80\%) (Shabo et al., 2005; El-Agamy et al., 2009).It is the reason that people who are suffering from symptoms of lactose intolerance can drink camel milk without any problem (Khaskheli et al., 2005).

Camels usually eat thorn and hard plants containing minerals; Therefore, different amounts of minerals are found in camel milk than bovine milk. As previous studies have shown, the amount of iron (about 10 times more than bovine milk) and copper in camel milk is more than bovine milk whilst some studies reported that the amount of calcium, magnesium, phosphor, sodium and potassium of camel milk is similar to bovine milk and the others reported high content of these minerals in camel milk (El-Agamy, 2006, 2009; Hashim et al., 2009; Konuspayeva et al., 2011; Ahmed et al., 2014).The average ash in one-humped camel milk and bovine milk is $0.8 \mathrm{~g} / 100 \mathrm{~g}$ and $0.7 \mathrm{~g} / 100 \mathrm{~g}$, respectively (Muehlhoff et al., 2013). The minimum daily requirement for calcium or phosphor is easily provided by 2.5 and 4 cups of camel milk respectively (El-Agamy, 2009). Due to iron deficiency, bovine milk causes hypochromic anemia in infants but this event is less seen in camel milk because of more iron content (Rao et al., 1970).

Heavy metals cause many harmful effects on human health such as saturnism (lead contamination), cancer (cadmium) (Konuspayeva et al., 2009). Long term accumulation of heavy metals via food may cause chronic effects in various organs such as heart, nervous system, liver and kidney of people 
(Saeedifar et al., 2014). There is not enough reported data on determination of minerals include calcium, copper, iron, zinc, sodium and potassium and heavy metals such as lead, cadmium, nickel, chromium in one-humped camel milk in Iran.

Considering the important role of minerals in human body health and the side effects of heavy metals, the aim of this study was to determine the amount of minerals as well as heavy metals of camel milk in Iran.

\section{Materials and methods}

\subsection{Materials}

Evaluation of mineral content and heavy metals were determined by nitric acid $65 \%$, hydrogen peroxide solution $30 \%$ and standard solutions of calcium, copper, iron, zinc, sodium, potassium, lead, cadmium, nickel and chromium. All chemicals which have been used in this study were analytical grade and purchased from Merck, Darmstadt, Germany.

\subsection{Sampling}

In this study, 25 camel milk samples were collected from seven regions of Iran. Samples examined belonged to Qazvin, Golestan, Semnan, Sistan-Baluchestan, Khuzestan, Bushehr and Tehran. To ensure the results, all experiments were performed three times.

\subsection{Sample preparation}

From every sample an amount of $0.300 \mathrm{~g}$ was weighted with $0.001 \mathrm{~g}$ accuracy in special containers for microwave digestion, then $5 \mathrm{~mL}$ of $65 \%$ nitric acid and $1 \mathrm{~mL}$ of $30 \%$ hydrogen peroxide. Prepared samples were digested by the lab microwave as programmed (in 3 step at pressure $40 \mathrm{~atm}$ : step $1,140{ }^{\circ} \mathrm{C}$ for 5 minutes and step $2,170{ }^{\circ} \mathrm{C}$ for 10 minutes, step $3,200{ }^{\circ} \mathrm{C}$ for 20 minutes, after that cooling for 40-45 minutes, The digested samples were filtered with a membrane filter (pore size $0.45 \mu \mathrm{m}$ ). The amount of minerals in samples was then measured by ICP-OES unit and standard solutions (Lante et al., 2006).

\subsection{Mineral determination}

The amount of minerals in samples was then measured in Iranian National Standards Organization using inductively coupled plasma optical emission spectrometer (ICP-OES),
IRIS Interpid II XSP Model and using five standard solutions $\left(10,50,100,500\right.$ and $\left.1000 \mu \mathrm{g} \mathrm{L}^{-1}\right)$ for each mineral.

\subsection{Statistical analysis}

Data were analyzed using SPSS 22.0 software (SPSS Inc, IBM, Chicago, IL) statistical software. One-way analysis of variance (One-way ANOVA) was performed and compare means took place through Duncan test $(p<0.05)$.

\section{Results and discussion}

\subsection{Mineral contents}

Table 1 shows the results of measuring the amount of calcium, copper, iron, zinc, sodium and potassium in the studied samples of camel milk.

The results obtained from measuring the amount of camel milk's calcium showed that the camel milk sample of Semnan region had the highest amount of calcium $(p<0.05)$. There was no significant difference among the samples from Ghazvin, Golestan and Khuzestan regions $(p \geq 0.05)$. According to the obtained data, the mean amount of calcium in raw camel milk samples in Iran was $944 \pm 37 \mathrm{mg} / \mathrm{L}$ different from the results of previous reported data from different countries (Figure 1). Sawaya et al. (1984) reported the amount of calcium in camel milk as $106 \mathrm{mg} / 100 \mathrm{~g}$. In 1998, Kappeler reported the amount of calcium in camel milk as 1060-1570 mg/L (Kappeler, 1998). Previous studies in China revealed that the amount of calcium in dromedary camel milk was between 30-197 mg/100 g which altered to $154.57 \mathrm{mg} / 100 \mathrm{~g}$ within 90 days lactation (Zhang et al., 2005). In another study by Konuspayeva et al. (2008) the mean value of calcium in camel milk in Kazakhstan was measured using

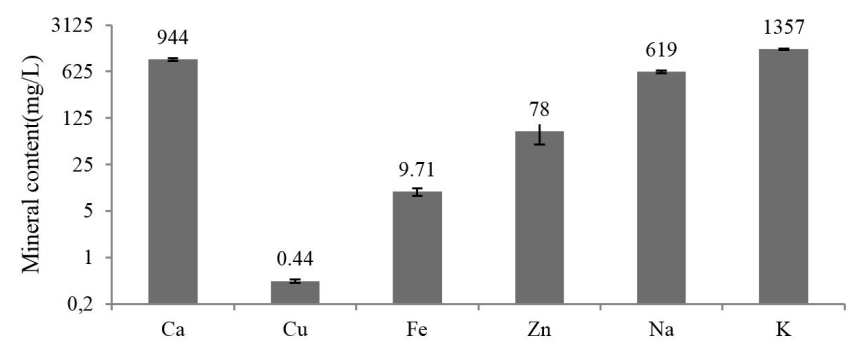

Figure 1. The amount of mineral contents camel's milk $(\mathrm{n}=25) \mathrm{mg} / \mathrm{L}$ (ppm).

Table 1. The mean values \pm standard error of minerals camel milk in seven regions of $\operatorname{Iran}(\mathrm{n}=25) \mathrm{mg} / \mathrm{L}(\mathrm{ppm})$.

\begin{tabular}{|c|c|c|c|c|c|c|c|}
\hline Minerals & Qazvin & Golestan & Semnan & $\begin{array}{c}\text { Sistan- } \\
\text { Baluchestan }\end{array}$ & Khuzestan & Bushehr & Tehran \\
\hline $\mathrm{Ca}$ & $1126^{b} \pm 52$ & $1039^{\mathrm{cb}} \pm 21$ & $1510^{a} \pm 91$ & $782^{d} \pm 31$ & $1229^{b} \pm 138$ & $834^{\mathrm{dc}} \pm 0$ & $846^{\mathrm{dc}} \pm 20$ \\
\hline $\mathrm{Cu}$ & $0.73^{a} \pm 0.03$ & $0.74^{\mathrm{a}} \pm 0.07$ & $0.41^{\mathrm{cb}} \pm 0.07$ & $0.32^{c} \pm 0.02$ & $0.53^{b} \pm 0.08$ & $0.35^{c} \pm 0.01$ & $0.42^{\mathrm{cb}} \pm 0.02$ \\
\hline $\mathrm{Fe}$ & $15.49^{a} \pm 2.47$ & $15.51^{\mathrm{a}} \pm 4.17$ & $12.54^{\mathrm{ba}} \pm 1.67$ & $5.69^{\mathrm{cb}} \pm 0.52$ & $13.87^{\text {ba }} \pm 0.01$ & $0.47^{c} \pm 0.01$ & $0.35^{\mathrm{c}} \pm 0.01$ \\
\hline $\mathrm{Zn}$ & $10^{\mathrm{b}} \pm 0$ & $12^{b} \pm 3$ & $527^{a} \pm 282$ & $48^{\mathrm{b}} \pm 13$ & $43^{b} \pm 21$ & $156^{\mathrm{b}} \pm 0$ & $6^{b} \pm 0$ \\
\hline $\mathrm{Na}$ & $472^{\mathrm{cb}} \pm 31$ & $431^{\mathrm{cb}} \pm 19$ & $533^{\mathrm{cb}} \pm 36$ & $668^{\text {ba }} \pm 43$ & $583^{\mathrm{cb}} \pm 70$ & $400^{c} \pm 0$ & $859^{a} \pm 52$ \\
\hline $\mathrm{K}$ & $1254^{\mathrm{cb}} \pm 7$ & $1180^{\mathrm{cb}} \pm 4$ & $1293^{\mathrm{cb}} \pm 35$ & $1429^{\mathrm{ba}} \pm 60$ & $1103^{\mathrm{cb}} \pm 34$ & $1076^{c} \pm 0$ & $1623^{a} \pm 42$ \\
\hline
\end{tabular}

Small letter in a row, showed significant differences with each other $(p<0.05)$. 
ICP method resulting in the amount of $1.232 \mathrm{mg} / \mathrm{L}$ indicating that change in season and species has a considerable effect on the amount of calcium.

Study on camel milk by atomic absorption method which took place by Shamsia in Egypt in 2009 reported the amount of calcium as $109 \mathrm{mg} / 100 \mathrm{~mL}$ (Shamsia, 2009). In 2010, Al haj and $\mathrm{Al}$ kanhal reported the mean value of calcium in camel milk as $114 \mathrm{mg} / 100 \mathrm{~g}$ (Al Haj \& $\mathrm{Al} \mathrm{Kanhal,} \mathrm{2010).} \mathrm{In} \mathrm{Lybia} \mathrm{the}$ amount of calcium in the milk of a camel kept in nourishing conditions (Suitable nourishment and water) and a camel kept in desert and low water conditions was measured and reported as $85.69 \mathrm{mg} / 100 \mathrm{~g}$ and $114.5 \mathrm{mg} / 100 \mathrm{~g}$, respectively (Alwan et al., 2014). Accordingly, the amount of calcium in the milk of camels living in desert conditions is more than the calcium found in the milk of camels living in nourishing conditions. Nnadozie et al. (2014) announced amount of calcium in camel milk in Nigeria as $0.51 \mathrm{mg} / \mathrm{kg}$.

In comparing regions, Elamin \& Wilcox (1992) reported that the amount of calcium in the milk of camels from Riyadh region of Saudi Arabia measured by atomic absorption spectroscopy was $30.03 \mathrm{mg} / 100 \mathrm{~g}$; while the study performed by Al-Wabel in Qassim region of Saudi Arabia measured the mean concentration of calcium up to $699.300 \mathrm{mg} / \mathrm{kg}$ (Al-Wabel, 2008).

Comparing with bovine milk, the amount of calcium in bovine milk from Qassim region in Saudi Arabia as reported by Al-Wabel was $661 \pm 41.95 \mathrm{mg} / \mathrm{kg}$ (Al-Wabel, 2008), while in 2014, Nnadozie et al. declared that the amount of calcium in bovine milk from Nigeria was $0.68 \pm 0.08 \mathrm{mg} / \mathrm{kg}$ (Nnadozie et al., 2014). In 2013, the range of calcium content in bovine milk was reported as 91 to $120 \mathrm{mg} / 100 \mathrm{~g}$ (Muehlhoff et al., 2013).

Camel milk sample from Golestan region contained the highest amount of copper $(p<0.05)$. There was no significant difference in this respect between the samples from Ghazvin and Golestan regions $(p \geq 0.05)$.

In present study, the amount of copper in raw camel milk was measured as $0.44 \pm 0.03 \mathrm{mg} / \mathrm{L}$ (Figure 1) which is different from the results of previous studies in other countries. In 2008, the mean concentration of copper in camel milk in Qassim region of Saudi Arabia was measured by Al-Wabel through ICP method resulting in the amount of $1.610 \mathrm{mg} / \mathrm{kg}$ (Al-Wabel, 2008). El-Agamy (2009) reported the amount of copper in camel milk as $0.11-1.5 \mathrm{mg} / \mathrm{L}$. In 2009, the amount of copper in camel milk in Egypt was measured at $0.19 \mathrm{mg} / 100 \mathrm{~mL}$ (Shamsia, 2009). In Lybia Alwan et al. (2014) reported the amount of copper in the milk of a camel kept in Suitable nourishment and water and a camel kept in desert and low water conditions as $0.14 \mathrm{mg} / 100 \mathrm{~g}$ and $0.24 \mathrm{mg} / 100 \mathrm{~g}$, respectively. The amount of copper in camel milk was measured by Nnadozie et al. as $0.161 \mathrm{mg} / \mathrm{kg}$ in Nigeria in 2014 (Nnadozie et al., 2014).

In Saudi Arabia the amount of copper in bovine milk from Qassim region was reported as $1.800 \pm 1.10 \mathrm{mg} / \mathrm{kg}$ (Al-Wabel, 2008 ) and in Nigeria was $0.143 \mathrm{mg} / \mathrm{kg}$ (Nnadozie et al., 2014). In another study, the amount of copper in bovine milk has been reported as very low (Muehlhoff et al., 2013).
The results of measuring the amount of iron showed that the highest amount of iron was found in the sample from Golestan region $(p<0.05)$. Furthermore, there was no significant difference among the samples from Ghazvin, Golestan, Semnan and Khuzestan regions $(p \geq 0.05)$.

In the present study, the amount of iron reached $9.71 \pm 1.34 \mathrm{mg} / \mathrm{L}$ (Figure 1) which is different from previous reports. Sawaya et al. (1984) measured the mean content of iron in camel milk samples and reached to $0.26 \mathrm{mg} / 100 \mathrm{~g}$. In 1998, Kappeler reported the iron concentration in camel milk as 1.3-2.5 mg/L (Kappeler, 1998). In another study by Konuspayeva et al. (2008), the mean amount of iron in raw camel milk in Kazakhstan was measured by ICP method resulting in the amount of $2.02 \mathrm{mg} / \mathrm{L}$. According to Shamsia's study in Egypt in 2009, the iron content in camel milk has been determined as $0.21 \mathrm{mg} / 100 \mathrm{~mL}$ (Shamsia, 2009). In 2009, El-Agamy reported the amount of iron in camel milk as 0.7-3.7 mg/L (El-Agamy, 2009). In study by Konuspayeva et al. (2010), the mean amount of iron in camel colostrum was measured by ICP method resulting in the amount of $2.50 \mathrm{mg} / \mathrm{L}$. Al Haj \& Al Kanhal (2010) and Nnadozie et al. (2014) reported the mean iron content in camel milk as $0.29 \mathrm{mg} / 100 \mathrm{~g}$ and $0.146 \mathrm{mg} / \mathrm{kg}$, respectively. Alwan et al. (2014) in Lybia reported that animal feed is an effective factor on the amount of iron in camel milk.

Comparing the obtained result in different regions revealed that the amount of iron in the milk of camels from Riyadh region of Saudi Arabia measured by atomic absorption spectroscopy was $0.28 \mathrm{mg} / 100 \mathrm{~g}$ (Elamin \& Wilcox, 1992), while the study performed by Al-Wabel in Qassim region of Saudi Arabia in 2008 measured the mean concentration of iron up to $2.981 \mathrm{mg} / \mathrm{kg}$ (Al-Wabel, 2008). The amounts obtained from these two regions of Saudi Arabia were similar.

Comparing with bovine milk, the amount of iron in bovine milk from Kazakhstan (Konuspayeva et al., 2008), Qassim region of Saudi Arabia (Al-Wabel, 2008) and Nigeria (Nnadozie et al., 2014) were reported as $0.35 \mathrm{mg} / \mathrm{L}, 4.214 \pm 1.78 \mathrm{mg} / \mathrm{kg}$ and $0.211 \mathrm{mg} / \mathrm{kg}$, respectively. The content of iron in bovine milk was reported $0.1 \mathrm{mg} / 100 \mathrm{~g}$ in the average (Muehlhoff et al., 2013).

The results indicated that the highest amount of zinc related to the sample from Semnan region $(p<0.05)$ while there was no significant difference among the samples from Ghazvin, Golestan, Sistan-Baluchestan, Khuzestan, Bushehr and Tehran $(p \geq 0.05)$.

The amount of zinc in camel milk samples of Iran obtained $78 \pm 28 \mathrm{mg} / \mathrm{L}$ (Figure 1), different from the results of other researches. In 1998, Kappeler reported the amount of zinc in camel milk as 4.0-5.0 mg/L (Kappeler, 1998). Al-Wabel in Saudi Arabia in 2008 measured the mean concentration of zinc by atomic absorption spectroscopy up to $1.480 \mathrm{mg} / \mathrm{kg}$ (Al-Wabel, 2008). In 2009, Shamsia obtained the amount of $0.19 \mathrm{mg} / 100 \mathrm{~mL}$ for the zinc concentration of camel milk in Egypt (Shamsia, 2009). El-Agamy (2009), Al Haj \& Al Kanhal (2010) reported the amount of zinc in camel milk as $2.8-4.4 \mathrm{mg} / \mathrm{L}$ and $0.53 \mathrm{mg} / 100 \mathrm{~g}$, respectively. Alwan et al. (2014) in Lybia, reported that the zinc content in camel milk in nourishing conditions $(0.42 \mathrm{mg} / 100 \mathrm{~g})$ was lower than camel milk which camel kept in desert and low water conditions $(0.58 \mathrm{mg} / 100 \mathrm{~g})$. The amount of zinc in camel 
milk was measured by Nnadozie et al. (2014) as $0.416 \mathrm{mg} / \mathrm{kg}$ in Nigeria.

In comparison with bovine milk, the value of zinc in camel milk was more than bovine milk. The zinc content in bovine milk from Qassim region of Saudi Arabia (Al-Wabel, 2008) and Nigeria (Nnadozie et al., 2014) was reported as $2.000 \pm 0.28 \mathrm{mg} / \mathrm{kg}$ and $0.432 \mathrm{mg} / \mathrm{kg}$, respectively. The range of zinc content in bovine milk was reported as 0.3-0.4 mg/100 g (Muehlhoff et al., 2013).

The results indicated that the highest amount of sodium related to the sample from Tehran region $(p<0.05)$ while there was no significant difference between the samples from Tehran and Sistan-Baluchestan ( $p \geq 0.05)$.

According to the obtained data, the content of sodium in camel milk samples of the present study was $619 \pm 28 \mathrm{mg} / \mathrm{L}$ (Figure 1). Sawaya et al. (1984) and Kappeler (1998) reported the amount of sodium in camel milk as $69 \mathrm{mg} / 100 \mathrm{~g}$ and $360-620 \mathrm{mg} / \mathrm{L}$, respectively. Zhang et al. (2005) by studying on dromedary milk using atomic absorption spectroscopy reported the content of sodium between $23-69 \mathrm{mg} / 100 \mathrm{~g}$ which altered to $72.0 \mathrm{mg} / 100 \mathrm{~g}$ within 90 days lactation. In 2009, Shamsia reported the amount of sodium in camel milk in Egypt as $58 \mathrm{mg} / 100 \mathrm{~mL}$ (Shamsia, 2009). Al Haj \& Al Kanhal (2010) and Nnadozie et al. (2014) reported the amount of sodium in camel milk as $59 \mathrm{mg} / 100 \mathrm{~g}$ and $110 \mathrm{mg} / \mathrm{kg}$, respectively.

The obtained data in different regions revealed that the content of sodium in the camel milk from Riyadh region of Saudi Arabia measured by atomic absorption spectroscopy was $43.10 \mathrm{mg} / 100 \mathrm{~g}$ (Elamin \& Wilcox, 1992), while the study performed by Al-Wabel in Qassim region of Saudi Arabia measured the mean content of sodium up to $115.870 \mathrm{mg} / \mathrm{kg}$ (Al-Wabel, 2008). Based on the results, the amount of sodium in these two regions of Saudi Arabia is different.

Comparing with bovine milk, the amount of sodium in bovine milk was reported as $91.60 \pm 3.45 \mathrm{mg} / \mathrm{kg}$ and $99.17 \pm 2.89 \mathrm{mg} / \mathrm{kg}$, respectively (Al-Wabel, 2008; Nnadozie et al., 2014). The range of sodium content in bovine milk was reported as $38-45 \mathrm{mg} / 100 \mathrm{~g}$ (Muehlhoff et al., 2013).

The results of measuring the amount of potassium showed that the highest amount of potassium was found in the sample from Tehran region $(p<0.05)$ while there was no significant difference between the samples from Tehran and Sistan-Baluchestan $(p \geq 0.05)$.

No significant difference among the samples from Ghazvin, Golestan, Semnan, Sistan-Baluchestan and Khuzestan was noticed $(p \geq 0.05)$.

In present study, the amount of potassium in camel milk samples obtained $1357 \pm 36 \mathrm{mg} / \mathrm{L}$ (Figure 1). Sawaya et al. (1984) and Kappeler (1998) reported the concentration of potassium in camel milk as $156 \mathrm{mg} / 100 \mathrm{~g}$ and $600-2100 \mathrm{mg} / \mathrm{L}$, respectively. Zhang et al. (2005) reported the amount of potassium between 60-214 $\mathrm{mg} / 100 \mathrm{~g}$ which altered to $191 \mathrm{mg} / 100 \mathrm{~g}$ within 90 days lactation. Shamsia (2009), Al Haj \& Al Kanhal (2010) and Nnadozie et al. (2014) reported the amount of potassium in camel milk as 179 mg/100 mL, 156 mg/100 g, 1133.33 mg/kg, respectively.

In comparing regions, Elamin \& Wilcox (1992) revealed that the amount of potassium in the milk of camels from Riyadh region of Saudi Arabia measured by atomic absorption spectroscopy was $72.48 \mathrm{mg} / 100 \mathrm{~g}$, while Al-Wabel (2008) in Qassim region of Saudi Arabia reported that the mean concentration of potassium up to $133.77 \mathrm{mg} / \mathrm{kg}$. Comparing the obtained results showed that the amount of potassium in these two regions of Saudi Arabia was different.

Comparing with bovine milk, the amount of potassium in bovine milk from Saudi Arabia and Nigeria reported as $113.700 \pm$ $5.84 \mathrm{mg} / \mathrm{kg}$ and $533.33 \pm 28.87 \mathrm{mg} / \mathrm{kg}$, respectively(Al-Wabel, 2008; Nnadozie et al., 2014). The range of potassium content in bovine milk was registered as 132 to $155 \mathrm{mg} / 100 \mathrm{~g}$ (Muehlhoff et al., 2013).

Elamin \& Wilcox (1992) declared that the difference in respect of the amount of minerals is due to genetic diversity and environmental factors and pastures.

In 1998, Kappeler stated that the amount of minerals and vitamins of camel milk depends on the nutrition, health status of the mammary glands and lactation period (Kappeler, 1998). Zhang et al. (2005) reported that diversity in the quantity of important minerals in camel milk could be related to race, nutrition, lactations period, drought and analysis methods. Al-Wabel (2008) explained that the quantity of minerals in camel milk depended on race, nutrition, lactation period, environmental conditions and production processes. The amount of minerals in the diet is very important for explaining the amount of calcium and zinc of the milk (Al-Wabel, 2008). As previously reported race, season and or region have no impact on the amount of iron in camel milk but season change and race have a significant impact on the quantity of calcium and phosphorus so that Bactrian camel milk has more calcium and phosphorus in comparison to dromedary camel milk. Also, the highest and lowest amount of calcium and phosphorus has been reported to be in spring and summer, respectively (Konuspayeva et al., 2008).

Al Haj \& Al Kanhal (2010) declared that the differences in the amount of minerals are related to the differences in race, nourishment and analysis methods. The quantity of main minerals in dromedary camel milk was different among Majaheim, Najdi, Wadah and Hjamra Hamra races.

Alwan et al. (2014) stated that there was no significant difference between fattened camels and desert ones (drought conditions) in respect of ash. The reason for higher amount of minerals in drought conditions in comparison to fattening conditions is generally accumulation of minerals in desert plants. They also reported that most of the milk factors' variety is due to differences in analytical methods used, geographical location, diet, race and lactation period.

The mean amounts of calcium and iron in camel milk in Iran were measured at $944 \pm 37$ and $9 \pm 1 \mathrm{mg} / \mathrm{L}$ respectively. The results of measuring some of minerals in camel milk in Iran are shown in Figure 1.

\subsection{Heavy metals}

Table 2 indicates the results of measuring the amounts of heavy metals in the studied samples of camel milk. According to these results, the milk samples from Ghazvin region had the highest amount of lead in comparison to other regions $(p<$ $0.05)$. The results showed that there was no significant difference among the samples from Ghazvin, Golestan, Semnan, Sistan- 
Table 2. The mean values \pm standard error of some heavy metals camel milk in seven regions of $\operatorname{Iran}(\mathrm{n}=25) \mu \mathrm{g} / \mathrm{L}(\mathrm{ppb})$.

\begin{tabular}{clcccccc}
\hline Mineral & Qazvin & Golestan & Semnan & $\begin{array}{c}\text { Sistan- } \\
\text { Baluchestan }\end{array}$ & Khuzestan & Bushehr & Tehran \\
\hline $\mathrm{Pb}$ & $8.28^{\mathrm{a}} \pm 2.93$ & $6.04^{\mathrm{a}} \pm 1.77$ & $7.78^{\mathrm{a}} \pm 3.87$ & $2.26^{\mathrm{a}} \pm 0.35$ & $6.55^{\mathrm{a}} \pm 2.99$ & $3.72^{\mathrm{a}} \pm 1.31$ & $2.60^{\mathrm{a}} \pm 0.43$ \\
$\mathrm{Cd}$ & $0.41^{\mathrm{ba}} \pm 0.22$ & $0.53^{\mathrm{ba}} \pm 0.13$ & $0.72^{\mathrm{a}} \pm 0.40$ & $0.13^{\mathrm{b}} \pm 0.01$ & $0.41^{\mathrm{ba}} \pm 0.18$ & $0.09^{\mathrm{b}} \pm 0.05$ & $0.14^{\mathrm{b}} \pm 0.01$ \\
$\mathrm{Ni}$ & $0.69^{\mathrm{a}} \pm 0.04$ & $0.59^{\mathrm{ba}} \pm 0.01$ & $0.59^{\mathrm{ba}} \pm 0.09$ & $0.48^{\mathrm{b}} \pm 0.03$ & $0.45^{\mathrm{b}} \pm 0.02$ & $0.45^{\mathrm{b}} \pm 0.00$ & $0.60^{\mathrm{ba}} \pm 0.03$ \\
$\mathrm{Cr}$ & $0.03 \pm 0.00$ & N.D & N.D & N.D & N.D & N.D $^{*}$ & N.D $^{*}$ \\
\hline
\end{tabular}

${ }^{*}$ N.D: Not Detected. Small letter in a row, showed significant differences with each other $(p<0.05)$.

Baluchestan, Khuzestan, Bushehr and Tehran in respect of lead amount $(p \geq 0.05)$.

About cadmium, the highest amount of this compound obtained for camel milk from Semnan region $(p<0.05)$ while there was no significant difference among the samples from Ghazvin, Golestan, Semnan and Khuzestan $(p \geq 0.05)$. Mean concentration of lead and cadmium was $4.46 \pm 0.65 \mu \mathrm{g} / \mathrm{L}$ and $0.30 \pm 0.05 \mu \mathrm{g} / \mathrm{L}$, respectively (Table 2 and Figure 2). According to Codex standard 193-1995, the maximum limit of lead for all kinds of milk is $0.02 \mathrm{mg} / \mathrm{L}$. There is no maximum limit for cadmium in this international standard (Codex Alimentarious Commission, 1995).

Based on the standards of Food and Agriculture Organization (FAO), World Health Organization (WHO) and Codex standard 193-2007, the determined limit for lead and cadmium is $20 \mu \mathrm{g} / \mathrm{kg}$ and $10 \mu \mathrm{g} / \mathrm{kg}$, respectively. The results of this study showed that the measured amounts of lead and cadmium in all samples were less than the acceptable limit.

The results showed that the sample from Ghazvin region had the highest amount of nickel $(p<0.05)$. There was no significant difference among the samples from Ghazvin, Golestan, Semnan and Tehran $(p \geq 0.05)$.

As shown in Table 2 and Figure 2, the mean value of nickel in this study was $0.53 \pm 0.02 \mu \mathrm{g} / \mathrm{L}$. According to Codex standard and World Health Organization (WHO), the limit in respect of mineral water is $20 \mu \mathrm{g} / \mathrm{L}$ and $70 \mu \mathrm{g} / \mathrm{L}$, respectively (Codex Alimentarious Commission, 2008). Previous study by Nnadozie et al. did not identify the amount of nickel in camel milk in Nigeria (Nnadozie et al., 2014).

The results of measuring the amount of chromium showed that it was identifiable only in Ghazvin region $(p<0.05)$ and in other regions in this study no chromium element was identified.

In this study no amount of chromium was detected in the raw camel milk samples in Iran except in Qazvin region (Table 2). In general, the amount of chromium in foodstuffs was considered to be $0.06 \mathrm{mg} / \mathrm{kg}$ of the fresh foodstuffs' weight (Ballantyne et al., 1999).

Nnadozie et al. (2014) reported the amount of chromium in camel milk in Nigeria as $0.191 \mathrm{mg} / \mathrm{kg}$.

In different regions, a study by Elamin and Wilcox in 1992 indicated the amount of lead in the milk of camels from Riyadh region of Saudi Arabia measured by atomic absorption spectroscopy to be $0.18 \mathrm{mg} / 100 \mathrm{~g}$ which is more than the amount of lead measured in the present study (Elamin \& Wilcox, 1992) while the study performed by Al-Wabel in Qassim region of Saudi Arabia in 2008 on the camel milk samples by atomic

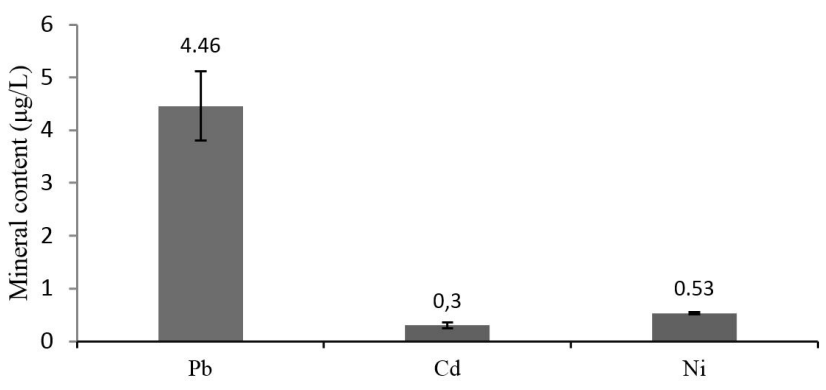

Figure 2. The amount of lead, cadmium and nickel camel's milk $(\mathrm{n}=25) \mu \mathrm{g} / \mathrm{L}(\mathrm{ppb})$.

absorption spectroscopy showed that camel milk lacked lead and cadmium (Al-Wabel, 2008). The amount of measured lead in two regions of Riyadh and Qassim in Saudi Arabia was different. In comparison with bovine milk, the amount of lead in bovine milk in Nigeria has been reported as $0.00 \mathrm{mg} / \mathrm{kg}$ (Nnadozie et al., 2014). No amount of chromium was traced in bovine milk in Nigeria (Nnadozie et al., 2014).

The amount of toxic minerals is affected with environmental pollution (Al-Wabel, 2008). The pollution probability of the samples with fuel of cars and agricultural machinery can be the main source of pollution with heavy metals. The race of camel has no effect on the amount of lead while the factor of season is very important and effective so that the amount of lead in camel milk in spring has had the least amount in comparison to other seasons (Konuspayeva et al., 2008). Despite the differences in soil conditions and scattering of mines in different regions, the standard limit has been considered in camel milk samples of all regions in this study.

The average amount of lead, cadmium and nickel in the camel milk samples in Iran were $4.46 \pm 0.65,0.30 \pm 0.05$ and $0.53 \pm 0.02 \mu \mathrm{g} / \mathrm{L}$, respectively.

Figure 2 shows the results of measuring the average amount of lead, cadmium and nickel in camel milk in Iran.

\section{Conclusions}

Among the beneficial elements, in Iran the amount of iron and zinc in camel milk samples where higher compare to bovine milk as well as it was mostly higher than previous studies of different regions. The amounts of other elements such as calcium, copper, sodium and potassium in camel milk samples of all studied regions were roughly equal to bovine milk. Despite the differences in soil conditions and scattering of mines in different regions, 
the amount of heavy metals (lead, cadmium and nickel) in the camel milk samples of all studied regions was in the acceptable level in comparison with international standards. No amount of chromium was traced in samples of raw camel milk in this study. The results of studies conducted in Iran showed that the amount of the pollution with lead and cadmium in bovine milk was much more than camel milk.

\section{Acknowledgements}

The support of Pharmaceutical Sciences Branch, Islamic Azad University (IAUPS) and Institute of Standards and Industrial Research of Iran, the University of Tehran are gratefully acknowledged. The authors would like to gratefully thank Parisa Ziarati for her kind support in this research.

\section{References}

Agrawal, R. P., Budania, S., Sharma, P., Gupta, R., Kochar, D. K., Panwar, R. B., \& Sahani, M. S. (2007). Zero prevalence of diabetes in camel milk consuming raica community of North-West Rajasthan, India. Diabetes Research and Clinical Practice, 76(2), 290-296. PMid:17098321. http://dx.doi.org/10.1016/j.diabres.2006.09.036.

Ahmed, A. A.-H., Galal-Sayed, R., \& Sayed, M. (2014). Nutritional value and sanitary evaluation of raw camel's milk. Emirates Journal of Food and Agriculture, 26(4), 317-326. Retrieved from http:// search.proquest.com/openview/882d6c2af5b8dd2fe61910207b8a e090/1?pq-origsite=gscholar.

Al Haj, O. A., \& Al Kanhal, H. A. (2010). Compositional, technological and nutritional aspects of dromedary camel milk. International Dairy Journal, 20(12), 811-821. http://dx.doi.org/10.1016/j.idairyj.2010.04.003.

Al-Wabel, N. A. (2008). Mineral contents of milk of cattle, camels, goats and sheep in the Central Region of Sudi Arabia. Asian Journal of Biochemistry, 3(6), 373-375. http://dx.doi.org/10.3923/ajb.2008.373.375.

Alwan, O. A., Igwegbe, A. O., \& Ahmad, A. A. (2014). Effects of rearing conditions on the proximate composition of Libyan Maghrebi Camels' (Camelus Dromedarius) milk. Internation Journal of Engineering and Applied Sciences, 4(8), 1-6.

Ballantyne, B., Marrs, T. C., \& Syversen, T. (1999).General and applied toxicology (3rd ed., pp. 2052-2155). London: Macmillan Publishers. Retrieved from http://eu.wiley.com/ WileyCDA/ WileyTitle/ productCd-0470723270.html.

Codex Alimentarious Commission. (1995). Codex general standard for contaminants and toxins in food and feed (Codex Standard 193-1995). Rome: Codex Alimentarius Commission. Retrieved from http://www.fao.org/fileadmin/user_upload/livestockgov/ documents/1_CXS_193e.pdf.

Codex Alimentarious Commission. (2008). Report of the Eighth Session of the Codex Committee on Natural Mineral Waters. Joint FAO/ WHO Food Standards Programme. Rome: Codex Alimentarius Commission. Retrieved from http://www.fao.org/input/download/ report/696/al31_20e.pdf.

El-Agamy, E. I. (2006).Camel milk. In Y. W. Park \& G. F. Haenlein (Eds.), Handbook of milk of non-bovine mammals. Oxford: Blackwell. Retrieved from http://samples.Sainsburysebooks. co.uk/9780470999721_sample_386290.pdf.

El-Agamy, E. I. (2009). Bioactive components in camel milk. In Y. W. Park (Ed.), Bioactive components in milk and dairy products. Oxford: Wiley-Blackwell. Retrieved from http://healingprovisions.
net/wp-content/uploads/2014/04/Bioactive-Components-in-Milkand-Dairy-Products-0813819822-Wiley.pdf.

El-Agamy, E. I., Nawar, M., Shamsia, S. M., Awad, S., \& Haenlein, G. F. W. (2009). Are camel milk proteins convenient to the nutrition of cow milk allergic children? Small Ruminant Research, 82(1), 1-6. http://dx.doi.org/10.1016/j.smallrumres.2008.12.016.

Elamin, F. M., \& Wilcox, C. J. (1992). Milk composition of Majaheim camels. Journal of Dairy Science, 75(11), 3155-3157. PMid:1460142. http://dx.doi.org/10.3168/jds.S0022-0302(92)78079-5.

Farah, Z., \& Rüegg, M. (1991). The creaming properties and size distribution of fat globules in camel milk. Journal of Dairy Science, 74(9), 2901-2904. http://dx.doi.org/10.3168/jds.S0022-0302(91)78472-5.

Farah, Z., Rettenmaier, R., \& Atkins, D. (1992). Vitamin content of camel milk. International Journal for Vitamin and Nutrition Research, 62(1), 30-33. PMid:1587705.

Farah, Z., Streiff, T., \& Bachmann, M. R. (1989). Manufacture and characterization of camel milk butter. Milchwissenschaft. Milk Science International, 44(7), 412-414. Retrieved from http://www. camelgate. com/pdf/milchwissenschaft_44_1989_412.pdf.

Hashim, I. B., Khalil, A. H., \& Habib, H. (2009). Quality and acceptability of a set-type yogurt made from camel milk. Journal of Dairy Science, 92(3), 857-862. PMid:19233778. http://dx.doi.org/10.3168/ jds.2008-1408.

Kappeler, S. (1998). Compositional and structural analysis of camel milk proteins with emphasis on protective proteins (Master's dissertation ETH, No. 12947). Swiss Federal Institute of Technology, Zurich. Retrieved from http://e-collection.library.ethz.ch/eserv/eth:22814/ eth-22814-02.pdf.

Khaskheli, M., Arain, M. A., Chaudhry, S., Soomro, A. H., \& Qureshi, T. A. (2005). Physico-chemical quality of camel milk. Journal of Agriculture and Social Sciences, 2, 164-166. Retrieved from https://www.researchgate.net/profile/Aijaz_Hussain_Soomro/ publication/237586369_PhysicoChemical_Quality_of_Camel_Milk/ links/00b495286ff9cc25c9000000.pdf.

Konuspayeva, G., Faye, B., \& Loiseau, G. (2011). Variability of vitamin C content in camel milk from Kazakhstan. Journal of Camelid Science, 4, 63-69. Retrieved from https://www.researchgate. net/profile/Bernard_ Faye/publication/266178544_Variability_of_vitamin_C_content_in_ camel_milk_from_Kazakhstan/links/542c224c0cf277d58e8af075.pdf.

Konuspayeva, G., Faye, B., Loiseau, G., Diacono, E., \& Akhmetsadykova, S. (2009). Pollution of camel milk by heavy metals in Kazakhstan. The Open Environmental Pollution \& Toxicology Journal, 1(1), 112118. http://dx.doi.org/10.2174/1876397900901010112.

Konuspayeva, G., Faye, B., Loiseau, G., Narmuratova, M., Ivashchenko, A., Meldebekova, A., \& Davletov, S. (2010). Physiological change in camel milk composition (Camelusdromedarius) 2: physico-chemical composition of colostrums. Tropical Animal Health and Production, 42(3), 501-505. PMid:19763867. http://dx.doi.org/10.1007/s11250009-9450-4.

Konuspayeva, G., Narmuratova, M., Faye, B., \& Loiseau, G. (2008). Variation factors of some minerals in camel milk. In B. Faye \& Y. Sinyaskiy (Eds.), Impact of pollution on animal products (pp. 125132). Berlin: Springer Sciences.

Lante, A., Lomolino, G., Cagnin, M., \& Spettoli, P. (2006). Content and characterisation of minerals in milk and in Crescenza and Squacquerone Italian fresh cheeses by ICP-OES. Food Control, 17(3), 229-233. http://dx.doi.org/10.1016/j.foodcont.2004.10.010.

Mankinen, K. S., \& Palosuo, T. (1992). A sensitive enzyme linked immune sorbent assay for determination of bovine Beta-Lactoglobulin in 
infant feeding formulas and human milk. Allergy, 47(4), 347-352. PMid:1456405. http://dx.doi.org/10.1111/j.1398-9995.1992.tb02070.x.

Muehlhoff, E., Bennett, A., \& McMahon, D. (2013). Milk and dairy products in human nutrition (pp. 41-253). Rome: FAO. Retrieved from http://www.cabdirect.org/abstracts/20133411376.html;jsessi onid=02B8C9C9BD1221AFD23BE92E674B5BDC.

Nnadozie, C. U., Birnin-Yauri, U. A., \& Muhammad, C. (2014). Assessment of some diary products sold in Sokoto Metropolis, Nigeria. International Journal of Advanced Research in Chemical Science, 1(10), 1-7. Retrieved from https://www.researchgate.net/ profile/U_Birnin-Yauri/publication/271209256_Assessment_of_some_ Diary_Products_Sold_in_Sokoto/links/54c219330cf2dd3cb9592652.pdf.

Rao, M. B., Gupta, R. C., \& Dastur, N. N. (1970). Camel milk and milk products. Indian Journal of Dairy Science, 23(2), 71-78. Retrieved from http://www. cabdirect.org/abstracts/19710405323.html.

Saeedifar, F., Ziarati, P., \& Ramezan, Y. (2014). Nitrate and heavy metal contents in eggplant (Solanum melongena) cultivated in the farmlands in the south of Tehran-Iran. International Journal of Farming and Allied Sciences, 3(1), 60-65.

Salami, M., Moosavi-Movahedi, A. A., Ehsani, M. R., Yousefi, R., Haertle, T., Chobert, J. M., Razavi, S. H., Henrich, R., Balalaie, S., Ebadi, S. A., Pourtakdoost, S., \& Niasari-Naslaji, A. (2010). Improvement of the antimicrobial and antioxidant activities of camel and bovine whey proteins by limited proteolysis. Journal of Agricultural and Food Chemistry, 58(6), 3297-3302. PMid:20175528. http://dx.doi. org/10.1021/jf9033283.
Sawaya, W. N., Khalil, J. K., Al-Shalhat, A., \& Al-Mohammad, H. (1984). Chemical composition and nutritional quality of camel milk. Journal of Food Science, 49(3), 744-747. http://dx.doi. org/10.1111/j.1365-2621.1984.tb13200.x.

Shabo, Y., Barzel, R., Margoulis, M., \& Yagil, R. (2005). Camel milk for food allergies in children. Immunology and Allergies, 7(12), 796-798. Retrieved from http://www.bio-asli.com/kopisusuunta/ downloadarticle/ar05dec-12.pdf. PMid:16382703.

Shamsia, S. M. (2009). Nutritional and therapeutic properties of camel and human milks. International Journal of Genetics and Molecular Biology, 1(2), 52-58. Retrieved from http://www.academicjournals. org/article/article1379512771_Shamsia.pdf.

Yasin, S. A., \& Wahid, A. (1957). Pakistan camels: preliminary survey. Agriculture Pakistan, 8, 289-297. Retrieved from http://www.cabdirect. org/abstracts/19581404476.html.

Zagorski, O., Maman, A., Yafee, A., Meisles, A., Van Creveld, C., \& Yagil, R. (1998). Insulin in milk: a comparative study. International Journal of Animal Science, 13, 241-244. Retrieved from http://www. vitalcamelmilk.com/pdf/zagorski-1998.pdf.

Zhang, H., Yao, J., Zhao, D., Liu, H., Li, J., \& Guo, M. (2005). Changes in chemical composition of Alxa Bactrian camel milk during lactation. Journal of Dairy Science, 88(10), 3402-3410. PMid:16162513. http:// dx.doi.org/10.3168/jds.S0022-0302(05)73024-1. 